\title{
Dining with the gods and the others: the banqueting tickets from Palmyra as expressions of religious individualisation
}

\section{Small objects and expressions of religious individualisation: the conundrum of archaeological evidence}

Much research on religion in the Roman world has focused on the collective and ritualised collectivity as defining traits; in the last decade, however, a new focus on experiences and the individual's role in religion has also emerged (Raja, Rüpke 2015, for a collection of articles taking such an approach; see also Rüpke 2016). These new ways of approaching ancient religion are part of a broader trend which insists that, in order to fully understand religious individualisation and propose a helpful framework for its contextualisation, we need to abandon our academic comfort zone and include aspects that lie beyond the often Western-centric (Eurocentric) way of understanding religion and religious individuality (e.g. Fuchs 2015).

While many disciplines working with material from the ancient Mediterranean world have tackled religion and individuals (or the lack of visible individuals!) through historical (written) and epigraphic sources and have used archaeological evidence as an illustration of this, grasping the individual and the process of individualisation is something that remains a challenge in archaeological research. Archaeological evidence often testifies to the 'end products' of processes, and evidence from the religious realm often only gives insight into processes that underline the collectivity of religion and its associated aspects, such as the architecture of sanctuaries, for example (Raja 2015d). However, over the

\footnotetext{
Note: I thank Jörg Rüpke and the ERC group ‘Lived Ancient Religion' for the past years of close collaboration within the framework of which thoughts about the Palmyrene tesserae have also been shared. I gratefully acknowledge the generous funding received from the Carlsberg Foundation for the Palmyra Portrait Project, without which this research could not have been undertaken. I also acknowledge with gratitude the support of the Danish National Research Foundation (grant number 119) for the Centre of Excellence for Urban Network Evolutions, which has granted new research opportunities feeding into research on Palmyra in general. Information about the Palmyra Portrait Project is available on the following webpage: http://projects.au.dk/palmyraportrait.
} 
past years, members of the 'Lived Ancient Religion' project, among others, have tackled such material, including also archaeological perspectives (Albrecht et al. 2018, also for further references), in order to bring to the forefront fruitful ways of engaging with material culture and the individual.

The present article attempts to determine the dynamics, and seemingly inherent tensions, between religious individualisation and standardised religious practices (Sartre, Sartre-Fauriat 2016, for general literature on Palmyra). The article tries to capture and lay open moments of individualisation in which seemingly strictly standardised religious practices are being loosened through an emerging or more clearly visible behavioural pattern. It does so by addressing the so-called banqueting tesserae of Palmyra - one of the most important groups which give us insight into the structure of religious life in Palmyra in the first three centuries CE (Raja 2015c; Raja 2016a, for recent research undertaken on the banqueting tesserae as well as further references).

The discussion will focus on how these tesserae might have been introduced at a certain point in the development of religious life in Palmyra as well as which type of individuality they express. The article will examine whether specific religious experiences and communicative efforts were related to the tesserae and how these objects framed (or reframed) the religious banquet - a common ritual in ancient Mediterranean religions. Furthermore, the constellations and situations that might have given rise or put a stop to individualisation will be identified in order to approach a typology of individualisation, based on the Palmyrene material.

Since the tesserae are mainly important because of their detailed iconography, in particular the visual language will be addressed as a means of understanding the above-mentioned aspects. Such an examination has the potential of yielding information about the dynamics between individualisation and institutionalisation; in other words, these tiny objects give insight into the processes of individual and group formations and dynamics and shed light on the trajectory of religious life from individual processes to institutionalisation and, thus, standardisation. However, these processes should be distinguished from pre-existing non-individualistic standardised and conformist practices. Thus they form their own processes of standardisation of the individualising practices themselves.

\section{The banqueting tesserae of Palmyra}

Ancient Tadmor, also known as Palmyra, flourished in the first three centuries CE (Sartre, Sartre-Fauriat 2016), in particular due to the trade relations of the city in which the city's elite played an active role (Seland 2014a; 2014b; 2015). Palmyra 
experienced continued growth until the Roman emperor Aurelian sacked Palmyra in $273 \mathrm{CE}$, after the uprising against the Romans, headed by the Palmyrene queen Zenobia (Hartmann 2001; Kropp, Raja 2016, for a collection of recent articles on the city). The city is today most known for the numerous well-preserved ruins dating to the first three centuries CE (Kaizer 2002, for the religious life of Palmyra; Raja 2015a, for the portraits and further literature; Gawlikowski 1973, for the architecture; Henning 2013, on the tower tombs; Smith 2013, for further literature on Palmyra's art, architecture and, in particular, history). However, apart from monumental remains, Palmyra is also home to a large corpus of so-called banqueting tesserae stemming from the city. The banqueting tesserae, of which there are several thousands and more than 1,100 distinct series, were catalogued in the 1950s (Ingholt, Seyrig, Starcky 1955, for the most extensive compilation of the tesserae; Dunant 1959, for further examples; Seyrig 1940, for an earlier publication on the tesserae and their relation to the ritual banquets in Palmyra). However, much has been learned about them since and, without a doubt, they represent the richest available source for understanding aspects of the religious life of Palmyra through their varied iconography and the inscriptions that many of them also carry.

While Palmyra is considered the only truly bilingual city of the Near East, with bilingualism being highly prevalent in the public sphere (Smith 2013, 16-21, for sources about the bilingualism of Palmyrene society; see also Yon 2012), the funerary and religious spheres in Palmyra were, nevertheless, highly monolingual. In these realms, the language remained the local Palmyrene Aramaic dialect. Another trait that made Palmyra unique is the fact that Palmyrene society merged local traditions with new ideas and imperial trends, as evidenced by archaeological and epigraphic sources (Raja 2015a, for a discussion of the ways in which Palmyrene funerary portraiture reflects local and imperial traditions). In this paper, examples of Palmyrene banqueting tesserae are considered in order to outline their role as central expressions and markers of situations and processes of individualisation within the religious sphere in Palmyrene society (Raja 2015a; $2015 \mathrm{~b}$, for recent discussions of other aspects of the banqueting tesserae). These tiny objects carried great importance in certain situations. They were media with a specific function. They served as entrance tickets to religious banquets, and after they had served this function, they seem to have lost their importance and were often left in the banqueting halls.

The interplay between highly individualised objects and the organisation of religious life in Palmyra stands at the centre of this contribution (for the most comprehensive treatment of religious life in Palmyra to date, see Kaizer 2002). Priests in Palmyra were the ones who commissioned the banqueting tesserae. This can be concluded from the iconography on the tesserae in which Palmyrene priests are depicted, usually reclining on a banqueting couch, most often 
alone but sometimes together with another priest, in what can be interpreted as banqueting scenarios. Sometimes, these priests are accompanied by inscriptions giving us their names and priestly titles. The Palmyrene priests can be recognised by their priestly clothes and, not least, their significant Palmyrene priestly hat, a cylindrical hat with a flat top - a shape that was unique for priestly dress in the Near East in the Roman period (Raja 2017a; 2018).

While reclining Palmyrene priests are the most common motif on one side of the tesserae, the other side of the banqueting tickets display a wide-ranging iconographic repertoire, within which some overarching groups can be distinguished; common motifs include busts of Palmyrene priests as well as representations of various deities and symbols for these. Votive and offering scenes - showing libations or incense offerings at altars - and banqueting settings are also depicted. A wide range of symbols, more or less well understood, including numerous interpreted as astral, are equally prominent within the tesserae iconographic repertoire. Furthermore, architectural elements are displayed, including, for example, temple fronts, parts of buildings and architectural frameworks, which may indicate that the banquets were set inside of buildings. Inscriptions are found on a large number of the tesserae; these may give the name of the person or group offering the banquet, names of deities, the date of the event or the measures of the food and drink given to each person. A large number of the depictions stem from signet seals, which would have belonged to certain individuals. It seems that the one who commissioned a series of tesserae often would have had his signet seal imprinted on one side, thereby making them even more recognisable as belonging to a particular individual. The signet seals often carry Roman motifs such as Greco-Roman deities, portraits of Roman-style men, as well as astrological symbols. These stand in contrast to the moulded motifs, which more often than not are made in a distinctively Palmyrene style. The highly diverse and varied iconographic language of the tesserae underlines that a high level of choice must have been involved every time a series of tesserae was produced. The tesserae motifs display a large range of iconographic elements, which were combined in numerous ways. Furthermore, they show how carefully the motifs were imprinted upon the tesserae. All these factors underline a process of individualisation, being signs of individual choice and expression clearly marked in the visual language: a process, however, which took place within a defined category of material, namely the tessera shape. No other kind of entrance tickets have been found in Palmyra.

The original name of the so-called banqueting tesserae is not known. They are not mentioned in any sources from Palmyra which speak about the religious life. However, since more than 1,100 different types exist, the tesserae must have played a central role in the religious life of Palmyra during the Roman period (Ingholt, Seyrig, Starcky 1955, for the corpus). The quite small tesserae, which were produced in 
series, measured between a few centimetres by another few up to approximately 5 by 5 centimetres (Al-As'ad, Briquel-Chatonnet, Yon 2005; Ingholt, Seyrig, Starcky 1955). For the largest part, they were produced in very finely levigated clay from which almost all impurities had been removed. This would have allowed for the visual elements to be imprinted more clearly in the wet clay. Some series were also produced in materials such as bronze, iron, lead and glass; however, these are rare and seem to have been exceptions (Hvidberg-Hansen, Ploug 1993, 23, for an introduction to the tesserae in general. They incorrectly state that these banquets were held in honour of dead priests; there are no indications, however, that this was the case (see also Gnoli 2016, for a recapitulation of the evidence speaking against such an interpretation)).

For each series of tesserae made in clay, two moulds with different reliefs were produced. These moulds seem to have been used only once, namely for the production of one single series of tesserae. By way of the moulds, a high relief could be produced on each side of the clay. A clay lump was placed between the two moulds, and the exact thickness of the tesserae would depend on how hard the moulds were pressed together. It is not known in what quantities the individual series were produced, but one find indicates that it could have been more than 100 (the only assumed complete series is published by Al-As'ad, Briquel-Chatonnet, Yon 2005, comprising 125 identical tesserae). However, each tessera was made carefully, and this shows that considerable attention was paid to making the tesserae within each series look as uniform as possible, perhaps in order to avoid falsifications.

A few tesserae are datable by their inscriptions, which give the date of the banquet (Ingholt, Seyrig, Starcky 1955, 22, no. 158, for a dated example; Hvidberg-Hansen, Ploug 1993, 189, I.N. 3206, for a tessera dated to 460 of the Palmyrene era, which equals 118/119 CE). The tesserae all seem to stem from the period between the late first century $\mathrm{CE}$ and the late third century CE, which is the period from which most of the archaeological evidence from Palmyra stems. However, purely stylistic datings of the tesserae are difficult to achieve, since the small objects make it hard to trace the typological development on more than a very broad scale. Apart from displaying a varied iconographic language, the tesserae also come in a wide variety of shapes. As such, the shape must likewise have been a parameter which was up for choice when commissioning a tesserae series.

The iconography of the tesserae was highly varied and detailed. In particular, when considering the size of the tesserae, it is striking how much attention was paid to iconographic details such as inscriptions, which were found on many of the tesserae. This fact in itself indicates that these objects carried a meaning that was conveyed explicitly and deliberately through the visual language. However, the importance of the object seems to have been lost after the event (the banquet), since the tesserae were largely left behind in the banqueting hall, from where they made their way into the drainage systems. This is one clear indication that the individualisation 
expression was confined to before the event, namely during the process of motif selection for the tesserae, and to the event itself, namely the entrance at the banquet (and potentially the moment when one received such a banqueting ticket).

The find spots of many of the tesserae, in and around the banqueting hall in the Sanctuary of Bel in Palmyra (Ingholt, Seyrig, Starcky 1955, III-V; see also Gawlikowski 2015, for a new contribution on Bel of Palmyra and for further bibliography), are indicators of their use and also of what seems to be a temporary use. Large numbers of tesserae were found in the drainage of the banqueting hall, which shows that the tesserae were not taken away after the event, and that guests left them there after having gained entrance. Thus, the tesserae had a very punctual function, so to say. They simply functioned as entrance tickets to religious banquets, which were hosted by Palmyrene priests - both as individuals and as groups; this is clear from the inscriptions, which often state names of priests or groups of priests and the deity to whom they dedicated the banquet (Ingholt, Seyrig, Starcky 1955, 91, for a number of these).

Furthermore, these tesserae could include a number of symbols, other inscriptions and iconographical elements (Kaizer, Raja 2019, for a symbol of the divine). On the one hand, they were highly individualised, and on the other hand, they were non-individualised and fitted into a category based on set parameters: material, iconographic language and inscriptions. In other words, these tesserae were, on the one hand, expressions of the choices of the individual Palmyrene priests, of whom there were many (Raja 2018, for a recent contribution on the visual representations of priests in Palmyra), and on the other hand, they were expressions of the organisation of religious life in Palmyra overall. Therefore, they represent a unique group of material through which the interplay between individualisation processes and institutional standards can be examined.

\section{The religious contexts of the banqueting tesserae: processes of individualisation within a structured religious universe}

In earlier contributions, I have discussed the ways in which the tesserae and the priestly iconography from Palmyra offer insight into the structure of Palmyrene religious life, which seems to have been heavily based on the involvement of elite male Palmyrene citizens who acted as priests (Raja 2017a; 2017b; for the tesserae, Raja 2016b). Through new studies of a comprehensive corpus of Palmyrene funerary sculpture, including the numerous depictions of Palmyrene priests, it is now possible 
to revisit the tesserae in the light of new knowledge about the structure of Palmyrene priesthoods and compare this with evidence from the tesserae (Raja 2017c).

Priestly representations make up approximately twenty-five per cent of all male funerary representations, which is a high and significant number. Furthermore, in the sarcophagi banqueting scenes, priests are often depicted together - fathers, uncles and sons - indicating that Palmyrene priesthoods were held within families and bestowed upon sons and nephews by more senior male family members (Raja 2016a, 130f., for the various categories of priestly representations; Raja 2016a, 142, for the argument that priesthoods were held within families). It has been argued elsewhere that there is reason to believe that Palmyrene priesthoods were passed on within families from fathers to sons, and that a father, most likely with the consent of the priesthood group, could also bestow priesthoods on several sons while still alive (Raja 2016a; 2017c). So, while being a status symbol which clearly indicated and underlined a certain position in society, Palmyrene priesthoods were also kept within families or extended families, likely for centuries. In this way, priesthoods were an important part of structuring Palmyrene society, both within and across the tribes or extended families that made up the basis of Palmyra's social and religious structure. Priesthood also became a way of maintaining order and continuity within Palmyrene religious life. In some ways, this would have allowed for little variation and choice in Palmyrene religious life, which seems to have been structured through continuity and traditions. However, the banqueting tesserae offered one way of individualising religious life and leaving an individual mark on religious ritual, since the individual priest could choose what he wanted to depict on these items when and if he hosted a religious banquet at some point during his time as a priest.

While the tesserae on the one hand tell us about the structure of religious life at Palmyra, and that religious banquets were part of ritual life, they also tell us that these banquets were reserved for certain people. The tesserae functioned as entrance cards to religious banquets, and this must have meant that there were people who were not invited to these events. We do not have any knowledge of how the tesserae were distributed or to whom. We also do not know whether further invitees, apart from those who held tickets and, therefore, most likely sat in the banqueting halls, could have sat in the porticoes of the sanctuaries, for example (Raja 2016b, 347-51, for the evidence for banqueting halls in Palmyra). Although such distribution practices remain unknown to us, the tesserae clearly indicate that a selection process was in place, and that a certain structure must have overarched the distribution patterns. The tesserae are therefore evidence for a certain practice, which was performed at Palmyra for centuries within the framework of Palmyrene religious life, and the only insight into the individualisation of such practice is what we gain from the iconography of the tesserae. Their visual language is the only indicator of the individual choices of the commissioners 
(Palmyrene priests). This leads to questions about the range of choices that were available and the limits that applied to such practices of individualisation.

While a set number of parameters come into play in tesserae imagery, including priestly iconography, symbols, deities and inscriptions, these could be mixed in a variety of ways, which allowed for the creation of unique series. It seems, indeed, to have been a wish or perhaps even a requirement that tesserae series differed from each other, which again opens the question of the degree to which the tesserae allowed for processes of individualisation to take place. However, since such a high degree of variety was involved, choice and, therefore, preference must have been in play. While the priestly iconography was static and did not differ across centuries, the other visual elements were highly diverse and could be mixed in numerous ways. One important aspect is the mix of iconographic styles encountered in the tesserae's visual language. While the moulded elements were depicted in a significantly Palmyrene, local iconographic tradition, the signet seal impressions often show Greco-Roman motifs, indicating that these signet seals might have been imported to Palmyra from other places (Raja 2016b, 353-61, for some examples). These signet seals also connect the tesserae with one specific individual, the commissioner of the tesserae series: one of the Palmyrene priests. It is interesting to note that, in the Palmyrene funerary sculpture, the Palmyrene priests and men often wear signet rings, showing that these items were indeed used in Palmyra.

Since the tesserae are most commonly found in the Palmyrene sanctuaries, and first and foremost the Sanctuary of Bel, it seems that they were only introduced with or after the monumentalisation of the Palmyrene sanctuaries. Through this monumentalisation, the structure of Palmyrene religious life would have been crystallised quite clearly to society, since religious architecture would have created a physical presence and setting for ritual practice. Thus, the individuality that was expressed through the tesserae's iconographic language was dependent on the overall structure of religious life and its cycles, and therefore, there were limits to the scope of its development. However, the tesserae did relate to the specific religious communal experience of the ritual banquet, but did so with an emphasis on the commissioning individual as the benefactor and central individual and the reason for the existence of that specific religious banquet (not of religious banquets per se). In other words, the tesserae reframed the religious banquet to be an event that, apart from the religious celebration, was also clearly a celebration (even if not officially) of the sponsor of the banquet. This certainly ties well into the euergetistic framework of Roman civic and religious communities. However, it also takes this framework one step further, since the tesserae so firmly place the individual, at least visually, on the same level as the deity/ies who were celebrated at the banquets. The god (receiver) and the donor (giver), so to say, became two sides of the same coin - in this case, the same tesserae. The Palmyrene priests 
become individualised through the visual repertoire on the tesserae, or at least claim a highly individualised position, by situating themselves on the same level as the local and non-local deities depicted on the tesserae. Other visual material, such as procession reliefs and votive scenes, stemming from the religious sphere in Palmyra, does not represent communication with deities and priests on the same lines. Therefore, in fact, the tesserae give us the strongest evidence for the importance and status of priests in Palmyra and constitute a unique group of material to gain further insights into the dynamics of individualisation processes.

\section{Conclusion}

The banqueting tesserae from Palmyra constitute the largest group of archaeological evidence from the city and give insight into the structure of religious life in Palmyra and the processes of individualisation within the religious sphere of the city. The Palmyrene banqueting tesserae seem to have been introduced after or along with the monumentalisation of the Palmyrene sanctuaries. They were connected to a certain practice, namely the ritual banquet, which took place in a controlled setting and to which only certain individuals were invited. The tesserae offered the sponsor of the banquet, one of several Palmyrene priests, a physical space to represent aspects which may be interpreted as parts of an individualisation process. This process was, however, limited by the material and by the fact that the religious banquets seem to have been exclusive events to which only a certain number of people were invited. Nonetheless, the Palmyrene banqueting tesserae remain an under-explored resource for understanding processes of individualisation within that which seems like a highly structured religious life with an emphasis on non-individualised values and on conformist practices. Palmyrene religious life seems to have operated within both extended local family structures, as indicated by the funerary evidence, and within the structures of adapted versions of association inspired by the Greco-Roman world, as the tesserae indicate, and at the same time, it was adapted to the overall structure of the Roman Empire. The tesserae give unique insight into attempts at individualisation within the scope of a highly structured religious framework based on an organisation run by Palmyrene priests, who all were members of the Palmyrene elite.

This contribution has examined and discussed how the Palmyrene banqueting tesserae were most likely introduced at a certain point in the development of the religious life of Palmyra, and how they express a certain type of individuality that emerged out of the physical structuring of Palmyrene religious life, which also limited individuality. It has also been shown how Palmyrene priests were situating themselves, visually at least, on the same level as the deities depicted on 
the tesserae. The importance of holding a Palmyrene priesthood was underlined through the use of the visual language repertoire and each priest was singled out of the group of Palmyrene priests through the individual depiction on the tesserae. Furthermore, this paper has addressed the specific religious experiences and communicative efforts that were related to the tesserae; it has been shown how these objects contributed to reframing the religious banquet - which was a common ritual in ancient Mediterranean religions, but which took on a specific character in Palmyra - by placing the donor of the banquet on the same item as the deity who was celebrated at the event. Finally, the structure of Palmyrene religious life has been outlined, and it has been shown that the religious banquet limited the degrees of individualisation. In other words, the type of individualisation visible within the framework of the Palmyrene material was both facilitated and constrained by the material, namely the tesserae themselves.

\section{Appendix}

\section{List of Illustrations}

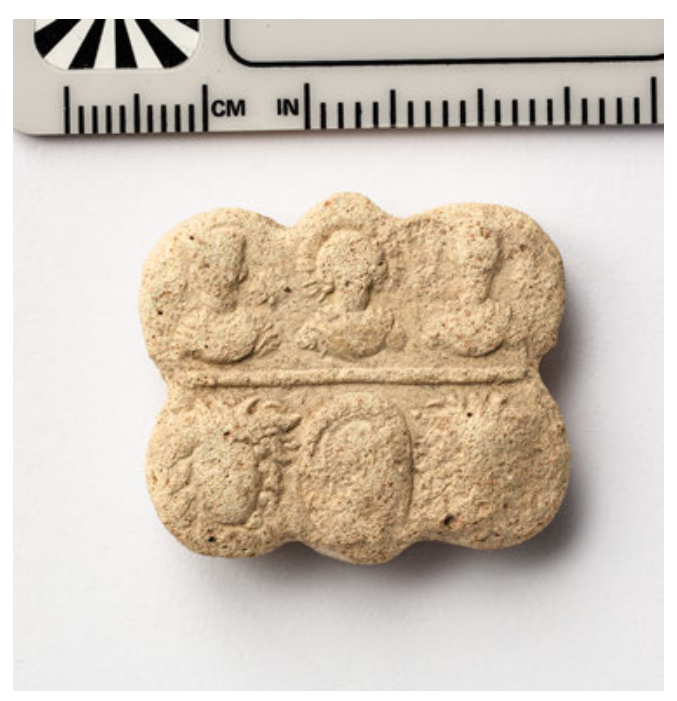

Fig. 1: Tessera (I.N. 3198) obverse in two registers. The upper register represents the god Sams/Malakbel between two busts of priests. The lower register shows a central signet seal with bust flanked by two Medusa busts. The tessera measures $3 \mathrm{~cm}$ in length, $2.7 \mathrm{~cm}$ in height and is $0.7 \mathrm{~cm}$ thick. (photo: Rubina Raja, courtesy of the Ny Carlsberg Glyptotek, Copenhagen) 


\section{VIN

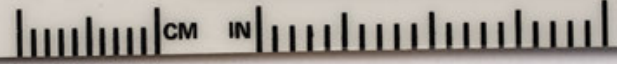

Fig. 2: Tessera (I.N. 3198) reverse depicting reclining Palmyrene priest. The inscription in Palmyrene Aramaic reads: '[Moqi]mu Zebid[a] Hai[ran]', which was the name of the priest. Measurements: same as above. (photo: Rubina Raja, courtesy of the Ny Carlsberg Glyptotek, Copenhagen)

\section{References}

Al-As'ad, Khaled; Briquel-Chatonnet, Françoise; Yon, Jean-Baptiste. 2005. 'The sacred banquets at Palmyra and the functions of the tesserae: Reflections on the tokens found in the Arșu Temple.' In A Journey to Palmyra: Collected Essays to Remember Delbert R. Hillers, ed. E. Cussini, Leiden: Brill. 1-10.

Albrecht, Janico et al. 2018. 'Remaking religion: The lived ancient religion approach', Religion. 1096-1151. Epub ahead of print: DOI: 10.1080/0048721X.2018.1450305.

Dunant, Claude. 1959. 'Nouvelle tessères de Palmyre', Syria 36. 102-10.

Fuchs, Martin. 2015. 'Processes of religious individualisation: Stocktaking and issues for the future', Religion 45 (3). 330-43.

Gawlikowski, Michat. 1973. Palmyre VI, Le temple palmyrénien: Études d'épigraphie et de topographie historique. Warszawa: PWN, Editions Scientifiques de Pologne.

Gawlikowski, Michat. 2015. 'Bel of Palmyra.' In Religious Identities in the Levant from Alexander to Muhammad: Continuity and Change, Contextualizing the Sacred 4, eds. M. Blömer, A. Lichtenberger, R. Raja, Turnhout: Brepols. 247-54.

Gnoli, Tommaso. 2016. 'Banqueting in honour of the gods: Notes on the marzeah of Palmyra.' In The World of Palmyra, Palmyrene Studies 1. Scientia Danica, Series H, Humanistica 4 (6), eds.

A. Kropp, R. Raja, Copenhagen: The Royal Danish Academy of Sciences and Letters. 31-41. Hartmann, Udo. 2001. Das palmyrenische Teilreich. Stuttgart: Franz Steiner Verlag. Henning, Agnes. 2013. Die Turmgräber von Palmyra: Eine lokale Bauform im kaiserzeitlichen Syrien als Ausdruck kultureller Identität. Rahden: Leidorf. 
Hvidberg-Hansen, Finn O.; Ploug, Gunhild. 1993. Palmyra-Samlingen. Copenhagen: Ny Carlsberg Glyptotek.

Ingholt, Harald; Seyrig, Henri; Starcky, Jean. 1955. Recueil des tessères de Palmyre. Paris: Imprimerie Nationale.

Kaizer, Ted. 2002. The Religious Life of Palmyra: A Study of the Social Patterns of Worship in the Roman Period. Oriens et Occidens 4. Stuttgart: Franz Steiner Verlag.

Kaizer, Ted; Raja, Rubina. 2019. 'Divine symbolism on the tesserae from Palmyra: Considerations about the so-called "symbol of Bel” or “Signe de la pluie”', Syria 95. 297-315.

Kropp, Andreas J. M.; Raja, Rubina (eds.). 2016. The World of Palmyra. Palmyrene Studies 1. Scientia Danica, Series H, Humanistica 4 (6). Copenhagen: The Royal Danish Academy of Sciences and Letters.

Raja, Rubina. 2015a. 'Palmyrene funerary portraits in context: Portrait habit between local traditions and imperial trends.' In Traditions: Transmission of Culture in the Ancient World, Acta Hyperborea 14, eds. J. Fejfer, M. Moltesen, A. Rathje, Copenhagen: Museum Tusculanum Press. 329-61.

Raja, Rubina. 2015b. 'Staging "private” religion in Roman "public" Palmyra: The role of the religious dining tickets (banqueting tesserae).' In Public and Private in Ancient Mediterranean Law and Religion, Religionsgeschichtliche Versuche und Vorarbeiten 65, eds. C. Ando, J. Rüpke, Berlin: De Gruyter. 165-86.

Raja, Rubina. 2015c. 'Cultic dining and religious patterns in Palmyra: The case of the Palmyrene banqueting tesserae.' In Festschrift für Inge Nielsen, Gateways 3, Hamburger Beiträge zur Archäologie und Kulturgeschichte des antiken Mittelmeerraumes, eds. S. Faust, M. Seifert, L. Ziemer, Aachen: Shaker Verlag. 181-200.

Raja, Rubina. 2015d. 'Complex sanctuaries of the Roman period.' In A Companion to the Archaeology of Religion in the Ancient World, eds. R. Raja, J. Rüpke, Chichester, West Sussex: Wiley Blackwell. 307-19.

Raja, Rubina. 2016a. 'Representations of priests in Palmyra: Methodological considerations on the meaning of the representation of priesthood in Roman period Palmyra', Religion in the Roman Empire 2 (1). 125-46.

Raja, Rubina. 2016b. 'In and out of Contexts: Explaining religious complexity through the banqueting tesserae from Palmyra', Religion in the Roman Empire 2 (3). 340-71.

Raja, Rubina. 2017a. "“You can leave your hat on": Priestly representations from Palmyra: Between visual genre, religious importance and social status.' In Beyond Priesthood: Religious Entrepreneurs and Innovators in the Roman Empire, Religionsgeschichtliche Versuche und Vorarbeiten 66, eds. R. Gordon, G. Petridou, J. Rüpke, Berlin: De Gruyter. 417-42.

Raja, Rubina. 2017b. 'To be or not to be depicted as a priest in Palmyra: A matter of representational spheres and societal values.' In Positions and Professions in Palmyra, Palmyrene Studies 2. Scientia Danica, Series H, Humanistica 4 (9), eds. T. Long, A. H. Sørensen, Copenhagen: The Royal Danish Society of Sciences and Letters. 115-30.

Raja, Rubina. 2017c. 'Networking beyond death: Family networks in Palmyra explored through the funerary sculpture.' In Sinews of Empire: Networks and Regional Interaction in the Roman Near East and beyond, eds. E. H. Seland, H. F. Teigen, Oxford: Oxbow. 121-36.

Raja, Rubina. 2018. "The matter of the palmyrene "modius": Remarks on the history of research of the terminology of the palmyrene priestly hat'. Religion in the Roman Empire 4 (2). 237-59. 
Raja, Rubina; Rüpke, Jörg. 2015. A Companion to the Archaeology of Religion in the Ancient World. Chichester, West Sussex: Wiley Blackwell.

Rüpke, Jörg. 2016. On Roman Religion: Lived Religion and the Individual in Ancient Rome. Townsend Lectures. Ithaca, NY: Cornell University Press.

Sartre, Maurice; Sartre-Fauriat, Annie. 2016. Palmyre: Vérités et légendes. Paris: Perrin.

Seland, Eivind H. 2014a. 'Caravans, smugglers and trading fairs: Organizing textile trade on the Syrian frontier.' In Textile Trade and Distribution in Antiquity, ed. K. Droß-Krüpe, Tübingen: Harrassowitz. 83-90.

Seland, Eivind H. 2014b. 'The organisation of the Palmyrene caravan trade', Ancient West and East 13.197-211.

Seland, Eivind H. 2015. 'Palmyrene long-distance trade: Land, river, and maritime routes in the first three centuries CE.' In The Silk Road: Interwoven History, eds. M. N. Walter, J. P. Ito-Adler, Cambridge, MA: Cambridge Institutes Press. 101-31.

Seyrig, Henri. 1940. 'Les tessères palmyréniennes et le banquet ritual.' In Mémorial Lagrange, Cinquantenaire de L’Ecole Biblique et Archèologique Francaise de Jerusalem 51, ed. L.-H. Vincent, Paris: J. Gabalda. 51-58.

Smith, Andrew M. 2013. Roman Palmyra: Identity, Community, and State Formation. Oxford: Oxford University Press.

Yon, Jean-Baptiste. 2012. Palmyre. Beirut: IFPO. 
